\title{
An Important Genetic Material for the Turkish Goat Production: The Maltese Goat
}

\author{
Cemil TÖLÜ*1, Türker SAVAŞ¹ \\ ${ }^{1}$ Çanakkale Onsekiz Mart University, Faculty Agriculture, Animal Science Department 17100, Çanakkale, \\ Turkey \\ Cemil TÖLÜ, ORCID No: 0000-0002-6135-4502, Türker SAVAŞ, ORCID No: 0000-0002-3558-2296
}

\begin{tabular}{|c|c|}
\hline ARTICLE INFO & A B S T RA C T \\
\hline Review & \multirow{14}{*}{$\begin{array}{l}\text { As is clearly understood from its name, the origin of Maltese goats come } \\
\text { from Malta Island. Different information exist about past of the Maltese } \\
\text { goats. Numbers of the goats that had been brought to our country long } \\
\text { time ago are in the critical threshold. In this study, some of the } \\
\text { morphologic and other characteristics of the genotype of Maltese goats } \\
\text { which have been husbandred in the experimental farm of Çanakkale } \\
\text { Onsekiz Mart University has been meticulously investigated. While } \\
\text { almost all the colors are observed in Maltese goats, black mottled and } \\
\text { red mottled are the dominant ones. The goats with long, broad and } \\
\text { baggy ears from the middle, are mostly hornless. In some individual of } \\
\text { the genotype which have weak breast connection to the body, excessive } \\
\text { baggy breast have been observed. Just as Maltese goats share similarity } \\
\text { with goat of Damascus and Kilis in terms of body size, they look like } \\
\text { goats of Kilis, Damascus, Hair, Norduz and Honamli in terms of live } \\
\text { weights. Maltese goats are quite promising with regard to kid production } \\
\text { because of high level of litter size ( } 2.4 \text { kid/goat), growing ability of kids } \\
\text { (123-209 g/day) and distinction of health features. Besides efficient milk } \\
\text { yield (108-539 kg/lactation) they have considerably good level of milk } \\
\text { protein and milk fat. As conclusion, the Maltese goat breed is a good } \\
\text { alternative for semi-extensive production conditions. }\end{array}$} \\
\hline This study was presented as an oral & \\
\hline presentation at the $23 r d$ & \\
\hline International $\quad$ Scientific-Experts & \\
\hline $\begin{array}{l}\text { Congress on Agriculture and Food } \\
\text { Industry Congress. }\end{array}$ & \\
\hline $\begin{array}{l}\text { Received : 26.02.2021 } \\
\text { Accepted : 06.05.2021 }\end{array}$ & \\
\hline Keywords & \\
\hline Genetic source & \\
\hline Morphology & \\
\hline Milk yield & \\
\hline Kid yield & \\
\hline Health & \\
\hline * Corresponding Author & \\
\hline cemiltolu@comu.edu.tr & \\
\hline
\end{tabular}

\section{Türkiye Keçi Yetiştiriciliği İçin Önemli Bir Değer: Malta (Maltız) Keçisi}

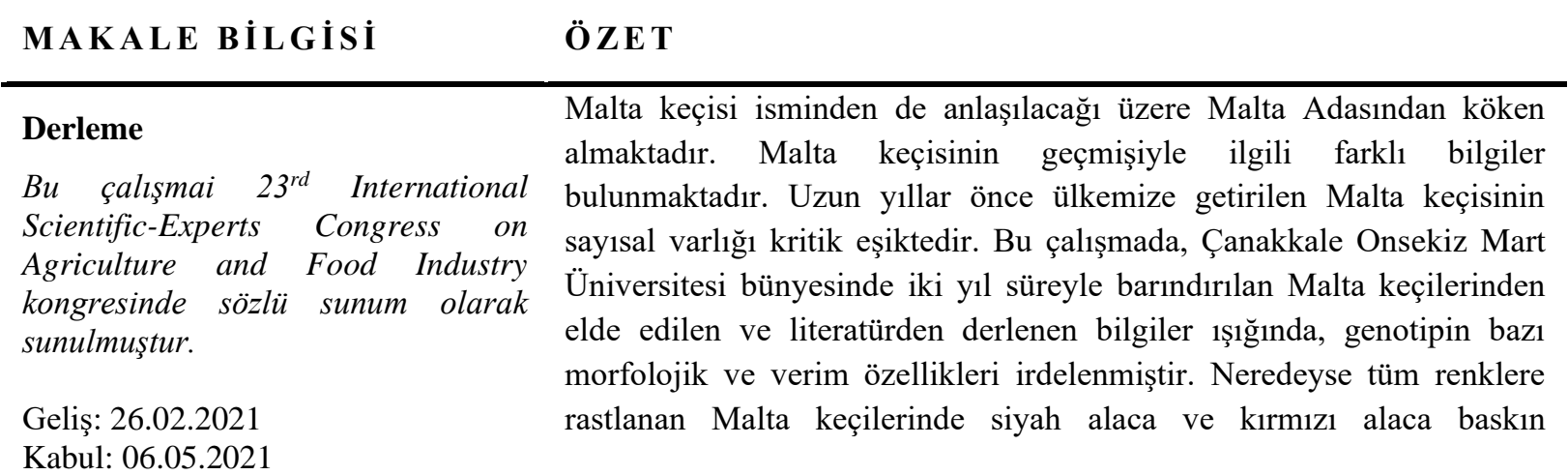




\begin{tabular}{ll}
\hline Anahtar Kelimeler & renklerdir. Uzun, geniş ve ortadan sarkık kulakları olan bu keçilerde, \\
Gen kaynağı & boynuzsuz hayvanlar çoğunlukta olmakla birlikte boynuzlu hayvanlara \\
Morfoloji & da rastlanmaktadır. Memenin vücuda bağlantısı zayıf olan genotipin bazı \\
Süt verimi & bireylerinde aşırı sarkık memelere rastlanmaktadır. Farklı yaş ve \\
Oğlak verimi & cinsiyetteki Malta keçilerinde belirlenen vücut ölçüleriyle Şam ve Kilis \\
Sağlı & keçilerine, canlı ağırlıkları bakımından Kilis, Şam, K1, Norduz ve \\
\hline \multirow{2}{*}{ Sorumlu Yazar } & Honamlı keçilerine benzerlik gösterdiği söylenebilir. Malta keçilerinin \\
cemiltolu@comu.edu.tr & yüksek düzeydeki oğlak verimi (2.4 oğlak/keçi), oğlakların büyüme \\
& yetenekleri (123-209 g/gün) ve sağlık özelliklerinin üstünlüğ̈ açısından \\
& oğlak üretimi bakımından umut vaat etmektedir. İyi durumdaki süt \\
& veriminin (108-539 kg/laktasyon) yanında süt protein ve süt yağ oranı \\
& da oldukça iyi düzeydedir. Malta keçisinin saf yetiştiriciliğine ve gen \\
& kaynakları kapsamında korunmasına yönelik proje ve çalışmalara \\
& başlanmalıdır. \\
\hline
\end{tabular}

\section{Introduction}

The proportion of the world's livestock breeds classified as being at risk of extinction increased from 15 percent to 17 percent between 2005 and 2014 and a further 58 percent of breeds are classified as being of unknown risk status. It is reported that $7 \%$ of the genotypes of domestic animal species were extinct (FAO, 2015). 14 of 20 native cattle genotypes and 2 of 19 sheep genotypes found in Turkey were extinct and of the sheep genotypes, 11 are endangered. In addition, 3 of 5 native goat genotypes found in our country are endangered too (Ertuğrul et al., 2005). Savaş (1995) mentioned that the protection of still valid native genotypes was difficult under the socioeconomic conditions concerned and, therefore, it was important to put forward the reasons for protection soon in order to determine the genotypes which should be absolutely protected.

In Turkey, goat breeding generally takes place in the form of the cross-breeding of native goats with goats of a foreign genotype (Şengonca, 2001). Nevertheless, the yield potential of our native genotypes should be revealed with the studies, in which detailed environmental control is performed. Although it is stated that the kid and milk yield traits of Maltese goats are at good levels (Sönmez et al., 1973; Özder, 2006; Tölü et al., 2010; Tölü ve Savaş, 2012), these goats are endangered in our country (Ertuğrul et al., 2005). As also expressed by Tölü and Savaş (2008), Maltese goats should also be absolutely utilized in the goat husbandry of our country besides Hair, Angora, Kilis, Norduz, Honamlı, Gökçeada, Damascus goats and the goat genotypes formed by cross-breeding.

In this study, it is aimed to introduce the Maltese goat that has been particularly reared in Western Anatolia for long years and that is striking with some of its superior traits. In the study, some morphological and yield traits of the genotype were studied in the light of the observations obtained from the Maltese goats housed within Çanakkale Onsekiz Mart University for two years and in the light of the information collected from the literature. 


\section{Its Origin}

As it will also be understood from its name, the Maltese goat, which is also called Maltese, in other words, of Malta, is supposed to have originated on the Malta Island. However, different reports on this matter are also striking. Özder (2006) states that the Maltese goat was formed as a result of efficient selection from the goats found on the Malta Island, while Blundell (1995) states that the genotype was brought from the Middle East and obtained as a result of selection from the local breeds on the island. On the other hand, it is reported that Maltese goats are a breed that originated in Italy and South Africa and that there are about 7000 heads in the southern sections of Italy (Carnicella et al., 2008). The Malta Island is a European Union country with an area of $316 \mathrm{~km}^{2}$ in Southern Europe. Maltese goats were also taken to some Mediterranean countries, as to our country. The primary ones among these countries are Italy, Libya, Greece and Algeria (Özder, 2006). On the other hand, Bhattacharya (1980) states that the Maltese goat was obtained as a result of the cross-breeding of Nubian and Spanish Murcia goats and that the color is reddish brown and black-spotted and reports that the breed spread to the other countries from Greece and Turkey.

The earliest information about the production of the Maltese goat in our country belongs to Vetulani (1934) and the first information on its yield traits was put forward in 1971 (Sönmez et al., 1971). It is seen that the production of Maltese goats, which were brought to our country long years ago, particularly concentrated on the Aegean coasts and in Istanbul and its environment. The information on the Maltese goat first began to be produced on the goats that were brought to the pen at Ege University in 1964 (Sönmez et al., 1971). The Maltese goat is produced both in pure form and through cross-breeding with native and foreign breeds and its levels of yield are in good condition (Sönmez et al., 1971; Sönmez et al., 1973; Sönmez and Kaymakçı, 1974; Şengonca et al., 1978; Bhattacharya, 1980; Tölü, 2009a).

\section{Body Sizes and Live Weight in Maltese Goats}

Almost all colors are encountered in Maltese goats, although cream, black and red are dominant colors. Red \& white and piebald goats are common. Hornless animals constitute the majority in these goats with long and wide (from time to time, animals which have ears with curling tips are encountered too) ears. The udder color might have different pigmentation according to the body color. The connection of the udder with the body is weak in these goats. Extremely drooping udders are encountered in some individuals (Figure 1; Tölü, 2009a). 

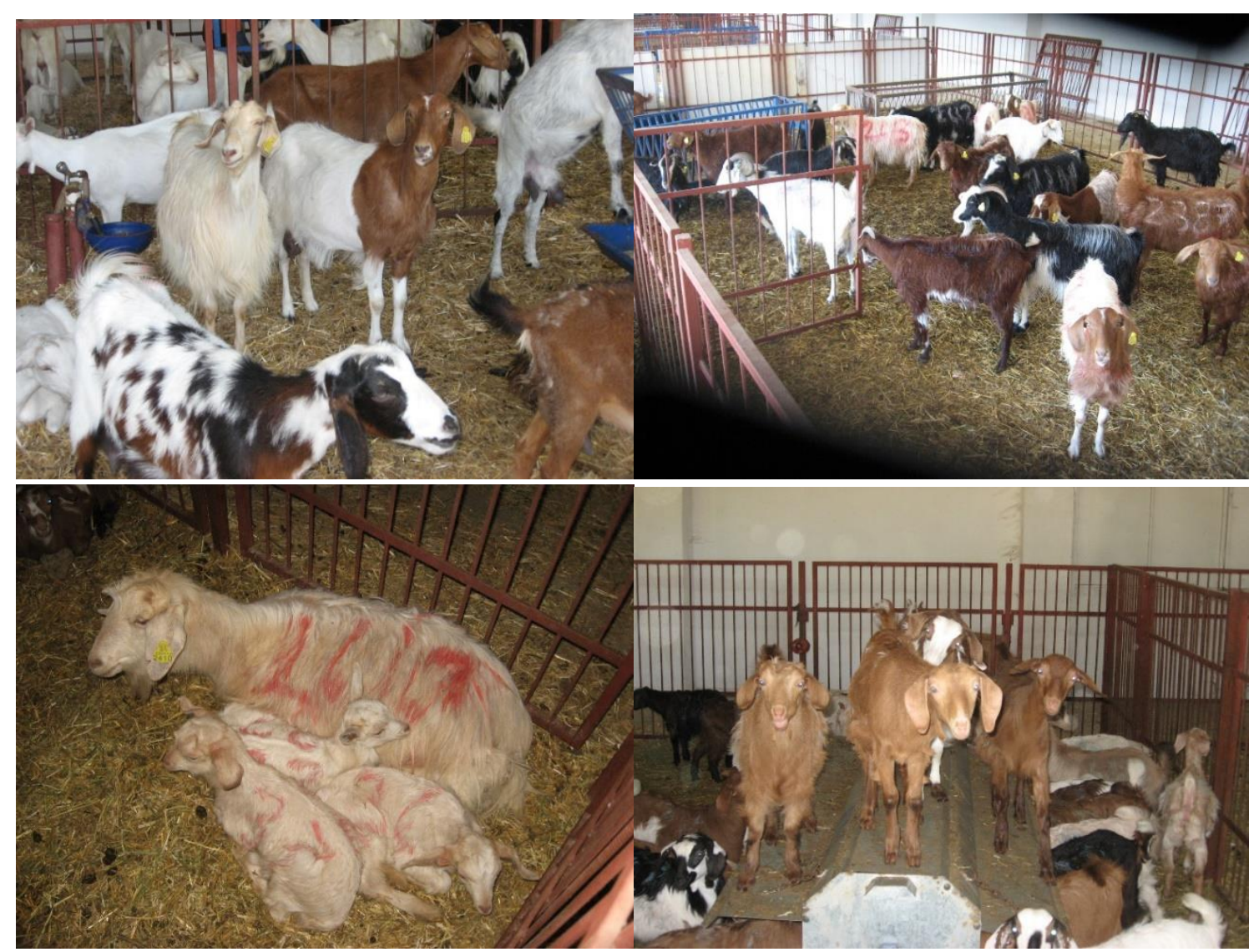

Figure 1. Maltese goats and kids (by C.Tölü)

Şekil 1. Malta keçileri ve oğlakları

The values of body size which were obtained from the goats with different ages in the Maltese genotype are presented in Table 1. It is striking that the Maltese goats display fast growth until weaning although they are born small (Table 1). The values of live weight determined according to ages in Maltese goats are seen in Table 2. When the Maltese genotype was first brought to the unit (Goat Husbandry Unit at Çanakkale Onsekiz Mart University), the mean live weight of the goats (aged 2-6 years) was determined as $39.9 \mathrm{~kg}$ and, in the following period, their live weights increased by 6-7 kg on average (Tölü, 2009a).

When the body sizes of Maltese goats are considered (Table 1), it might be stated that they resemble Damascus and Kilis goats, while they have a larger body structure than our other native breeds (Soysal et al., 2003; Keskin and Gül, 2006; Şimşek and Bayraktar 2006; Vatansever and Akçapınar, 2006; Anonymous, 2008a,b). The live weights of Maltese goats resemble the live weights of Kilis, Damascus, Hair, Norduz and Honaml goats, whereas they are higher than that of the Angora goat (Soysal et al., 2003; Keskin and Gül, 2006; Özder, 2006; Şimşek and Bayraktar 2006; Vatansever and Akçapınar, 2006; Anonymous, 2008a,b). 
Table 1. Mean, standard deviation (SD), the lowest (min) and the highest (max) values of some body sizes in Maltese goats (Tölü, 2009a)

Tablo 1. Malta keçilerinde bazı vücut ölçülerine ait ortalama ( $\bar{x}$ ), standart sapma (SS), en düşük ve en yüksek değerleri (Tölü, 2009a)

\begin{tabular}{|c|c|c|c|c|}
\hline \multirow{2}{*}{ Traits (cm) } & \multicolumn{4}{|c|}{ Birth (0-3 days) } \\
\hline & Mean & SD & Minimum & Maximum \\
\hline Body length & 29.4 & 2.1 & 24.0 & 34.0 \\
\hline Height of withers & 31.8 & 1.9 & 27.0 & 36.0 \\
\hline Heart girth & 32.5 & 2.8 & 22.0 & 39.0 \\
\hline Heart depth & 12.4 & 0.8 & 11.0 & 14.0 \\
\hline Rump height & 31.3 & 1.9 & 26.0 & 35.0 \\
\hline Rump depth & 10.6 & 0.8 & 9.0 & 13.0 \\
\hline \multirow[t]{2}{*}{ Rump width } & 3.6 & 0.4 & 2.9 & 4.8 \\
\hline & \multicolumn{4}{|c|}{ Weaning (60 days) } \\
\hline Body length & 47.6 & 3.6 & 39.0 & 56.0 \\
\hline Height of withers & 47.3 & 3.1 & 41.0 & 54.0 \\
\hline Heart girth & 51.6 & 4.3 & 40.0 & 62.0 \\
\hline Heart depth & 20.2 & 1.9 & 18.0 & 28.0 \\
\hline Rump height & 46.9 & 3.2 & 40.0 & 54.0 \\
\hline Rump depth & 18.6 & 2.0 & 16.0 & 26.0 \\
\hline Rump width & 6.0 & 0.7 & 4.5 & 7.9 \\
\hline Ear length & 14.4 & 1.4 & 11.0 & 18.0 \\
\hline \multirow[t]{2}{*}{ Ear width } & 5.9 & 0.6 & 5.0 & 8.0 \\
\hline & \multicolumn{4}{|c|}{ Female yearling (14 months) } \\
\hline Body length & 66.4 & 4.8 & 59.0 & 79.0 \\
\hline Height of withers & 63.5 & 3.5 & 58.0 & 70.0 \\
\hline Heart girth & 68.1 & 4.2 & 60.0 & 76.0 \\
\hline Heart depth & 27 & 2.7 & 21.0 & 31.0 \\
\hline Rump height & 61.7 & 3.4 & 57.0 & 68.0 \\
\hline Rump depth & 25.5 & 2.1 & 23.0 & 30.0 \\
\hline Rump width & 9.1 & 0.7 & 8.1 & 10.2 \\
\hline Ear length & 19.0 & 2.9 & 16.0 & 29.5 \\
\hline \multirow[t]{2}{*}{ Ear width } & 7.3 & 0.6 & 6.2 & 8.8 \\
\hline & \multicolumn{4}{|c|}{ Goat (2-6 years) } \\
\hline Body length & 77.1 & 4.5 & 61.0 & 85.0 \\
\hline Height of withers & 71.1 & 3.5 & 64.0 & 77.0 \\
\hline Heart girth & 83.1 & 3.6 & 79.0 & 92.0 \\
\hline Heart depth & 34.2 & 1.7 & 30.0 & 39.0 \\
\hline Rump height & 69.0 & 2.8 & 62.0 & 74.0 \\
\hline Rump depth & 30.8 & 2.2 & 27.0 & 35.0 \\
\hline Rump width & 11.0 & 0.9 & 8.9 & 12.8 \\
\hline Ear length & 20.0 & 2.0 & 17.5 & 25.0 \\
\hline Ear width & 8.0 & 0.7 & 7.0 & 9.5 \\
\hline
\end{tabular}


Table 2. Mean and standard deviation (SD) values of live weights according to ages in Maltese goats (Tölü, 2009a)

Tablo 2. Malta keçilerinde yaşlara göre canlı ağırlıklara ait ortalama $(\bar{x})$ ve standart sapma (SS) değerleri (Tölü, 2009a)

\begin{tabular}{ccc}
\hline Age (year) & Mean & SD \\
\hline 1 & 29.83 & 5.30 \\
2 & 42.28 & 4.44 \\
3 & 43.84 & 5.54 \\
4 & 46.30 & 5.47 \\
5 & 52.87 & 6.70 \\
6 & 54.29 & 2.49 \\
\hline
\end{tabular}

\section{Reproduction and Growth Traits}

In the Maltese genotype reared within the framework of a TÜBİTAK (the Scientific and Technological Research Council of Turkey) project (106 O 411) in the Goat Husbandry Unit at Çanakkale Onsekiz Mart University, the number of kids per kidding goat was 1.9 in the first year and 2.4 in the second year (Tölü, 2009a). In the previous studies in Turkey, it was determined that the kid yield in Maltese goats was 1.847 per goat (Sönmez et al., 1971) and 1.8 on the Malta Island (Blundell, 1995). It is known that the number of kids per goat is 0.79-1.18 in Hair goats (Sönmez, 1974; Özder, 2006; Şengonca et al., 2003; Şimşek et al., 2006), 1.3 in Saanen x Hair goat crossbreeds (Şengonca et al., 2003), 1.6-1.8 in Gökçeada goats (Tölü and Savaş, 2010), 1.2-1.5 in Kilis goats (Güney et al., 1995; Soysal et al., 2003), and 1.6-1.9 in Damascus goats (Keskin and Gül, 2006). It is seen that the kid yields of the Maltese goat are also higher than those of Saanen (1.7), Alpine (1.7), Nubian (2.0) and Toggenburg (1.6) goat breeds (Amoah et al., 1996).

It was determined that the Maltese kids with a birth weight ranging from 2.9 to $3.0 \mathrm{~kg}$ reached 9.6-11.8 $\mathrm{kg}$ at weaning (40-60 days) with a daily live weight increase by $129-162 \mathrm{~g}$ (Tölü, 2009a). The birth weights range from 2.95 to $3.70 \mathrm{~kg}$ in Saanen x Hair crossbreeds and from 2.63 to $2.77 \mathrm{~kg}$ in the kids of pure Hair goat (Şengonca et al., 2003; Şimşek and Bayraktar, 2006). They were reported as $3.1 \mathrm{~kg}$ for Norduz kids (Kurk et al., 2004), between $2.76 \mathrm{~kg}$ and $2.84 \mathrm{~kg}$ for the kids of the Angora goat (Vatansever and Akçapınar, 2006), and between 2.74 and $3.57 \mathrm{~kg}$ for the kids of Bornova genotype (Duman and Demirören, 2002). The weaning weights were reported as $11.8 \mathrm{~kg}$ (Şimşek and Bayraktar, 2006) and $12.1 \mathrm{~kg}$ (Şengonca et al., 2003), for Hair goats at 60 days of age and as 9-10 kg for Damascus goats at 60-90 days of age (Keskin and Gül, 2006), and $16 \mathrm{~kg}$ of live weight was reported for Honaml goats at 90 days of weaning age (Anonymous, 2008a). Nevertheless, it is expressed that the Alpine kids, reach $15 \mathrm{~kg}$ at 60 days of age (Morand-Fehr et al., 2002). As it will be seen, the Maltese genotype resembles the above-mentioned genotypes in terms of weaning weights; however, it reaches these weights earlier. Sönmez et al. (1971) report that the live weight increase ranges from $123 \mathrm{~g}$ to $209 \mathrm{~g}$ in Maltese kids until 12 weeks of age.

It was determined that the Maltese yearlings which particularly displayed fast growth until weaning reached $43 \%$ of the breeding season live weights of adult goats in the breeding 
season (at 6-8 months of age) (Tölü, 2009a). The same value is 55.6\% for Turkish Saanen goats (Tölü et al., 2009). They state that in dairy goat husbandry, the females might be used in breeding at 7-8 months of age when they reach 55\% of the adult live weights (Morand-Fehr et al., 2002).

\section{Milk Yield Traits}

It was determined that the mean milk yields of Maltese goats were $330.4 \mathrm{~kg}$ and 275.4 $\mathrm{kg}$ in lactation lengths of 238-264 days, respectively (Tölü, 2009a). It was reported that the mean lactation length was 150-162 days in Hair goats (Sönmez, 1974; Şengonca et al., 2003; Şimşek et al., 2006), 232.75 days in Bornova goat (Şengonca et al., 2002), 201.49 days in Saanen x Hair goat crossbreeds (Şengonca et al., 2003), and 244.5 days and 257.6 days in Damascus goats and German Fawn Goat x Hair goat $\mathrm{G}_{1}$ crossbreeds, respectively (Güler et al., 2007).

In Hair goats, the lactation milk yield ranges from 70 to $160 \mathrm{~kg}$ (Sönmez, 1974; Bhattacharya, 1980; Şengonca et al., 2003; Şimşek et al., 2006). The lactation milk yield was reported as $75 \mathrm{~kg}$ in Angora goats (Yertürk and Odabaşığlu, 2007), 200-300 kg in Kilis goats (Güney et al., 1995; Soysal et al., 2003), 330-350 kg in Damascus goats (Keskin et al., 2004; Güler et al., 2007), 135-216 kg in Honaml goats (Anonymous, 2008a) and 66-222 kg in Norduz goats (Anonymous, 2008b). On the other hand, the lactation milk yield is reported as 226-350 kg for Maltese goats (Sönmez et al., 1971; Blundell, 1995; Carnicella et al., 2008). It might be stated that the milk yields of Maltese goats are close to those of Damascus and some foreign breed crossbreeds.

In Maltese goats, the mean milk fat, milk protein and milk dry matter were determined as $4.92-5.46 \%, 3.42-3.41 \%$ and $14.2-14.7 \%$, respectively (Tölü, 2009a). Depending on İzmen (1940), Bhattacharya (1980) provides the rates of milk fat and milk protein for Hair goats as $5.5 \%$ and $4.8 \%$, respectively, and Soysal et al. (2003) provide the rate of milk fat as 5-5.5\% again in Hair goats and $4.7 \%$ in Kilis goats. The milk fat and the milk protein are reported as 4.3\% and 3.5\% in Damascus goats, respectively, whereas the milk fat and the milk protein are reported as $4.1 \%$ and $3.4 \%$ in German Fawn Goat $x$ Hair goat $\mathrm{G}_{1}$ crossbreeds, respectively (Keskin et al., 2004). On the other hand, Güler et al. (2007) determined that the milk fat was $4.02 \%$ in Damascus goats and $4.55 \%$ in German Fawn Goat $x$ Hair Goat $\mathrm{G}_{1}$ crossbreeds. The milk fat and the milk protein were determined as 3.5\% and 3.4\% in Maltese goats in Italy, respectively (Carnicella et al., 2008), whereas the milk fat and the milk protein were determined as 3.8\% and 3.3\% in Maltese goats on the Malta Island, respectively (Blundell, 1995). As it is seen, the Maltese genotype has particularly higher values of milk fat $(4.92 \%$, $5.46 \%)$ than, and values of milk protein $(3.42 \%, 3.41 \%)$ similar to, those of the native goat genotypes reared in our country.

\section{Animal Health}

In a comparative study on the kids of Gökçeada, Maltese and Turkish Saanen goat genotypes in terms of cases of diarrhea, the cases of diarrhea were observed significantly less in the Maltese genotype as compared to the other genotypes (Tölü, 2009b). Also in the case of 
Ecthyma (Ecthyma contagiosum) experienced in the same genotypes, the disease progressed in a significantly milder way in the Maltese kids than in the other genotypes (Tölü et al., 2011). In another study on Gökçeada, Maltese and Turkish Saanen genotypes, it was determined that the health application per animal was made at a lower level in the Maltese genotype than in the other genotypes (Tölü and Savaş, 2011). In the light of the evaluations on health, the Maltese genotype has significant potential particularly when the inadequate environmental conditions experienced in the goat husbandry in our country are taken into consideration.

\section{Conclusions}

The fact that it was difficult to find the pure Maltese goat, which was sought under field conditions in order to purchase within the scope of the TÜBITAK project, reinforces the phenomenon which was put forward by Ertuğrul et al. (2005) and which expresses that the genotype is seriously threatened by cross-breeding. However, this genotype is promising with its quite high kid yield, the growing abilities of kids and its superiority in terms of health traits. Besides its milk yield that might be considered adequate, its rates of milk protein and milk fat are also at quite good levels. Maltese goat breed is a good alternative for semiextensive production conditions, especially in Turkey. Projects and studies on the pure production of the Maltese goat and its protection within the scope of gene sources should be carried on with precedence.

\section{References}

Amoah, E.A., Gelaye, S., Guthrie, P., Rexroad Jr, C.E., 1996. Breeding season and aspects of reproduction of female goats. Journal of Animal Science. 74: 723-728.

Anonymous, 2008a. Honaml1 Keçisi. http://marmarahae.gov.tr/irklar/sa.onamli.pdf (19.02.2008).

Anonymous, 2008b. Norduz Keçisi.

http://www.tagem.gov.tr/sa.gk/milli_irk_tescil_listesi_taslagi_keci_norduzkecisi.htm (19.02.2008).

Bhattacharya, A.N., 1980. Research on goat nutrition and management in Mediterranean Middle East and adjacent Arab countries. Journal of Dairy Science. 63: 1681-1700.

Blundell, R., 1995. Reintroduction of the Local Breeds of Sheep and Goats in Malta. Gabina D. (ed.) In: "Strategies for Sheep and Goat Breeding: CIHEAM-IAMZ, (231p). Meeting of the Joint FAO/ CIHEAM Network on Sheep and Goats, Sidi-Thabet, TUNISIA. 26-28 March, 1995, p. 97-100.

Carnicella, D., Dario, M., Ayres, M.C.C., Laudadio, V., Dario, C.,. 2008. The effect of diet, parity, year and number of kids on milk yield and milk composition in Maltese goat. Small Ruminant Research. 77: 71-74.

Duman, A., Demirören, E., 2002. Süt tipi oğlakların doğum, 30. gün ve 60. gün canlı ağırlıkları üzerine sistematik çevre etmenlerinin etkileri. Ege Üniversitesi Ziraat Fakültesi Dergisi. 39: 73-78. 
Ertuğrul, M., Dellal,G., Elmacı, C., Akın, O., Karaca, O., Altın, T., Cemal, İ., 2005. Hayvansal gen kaynaklarının koruma ve kullanımı. Türkiye Ziraat Mühendisliği VI. Teknik Kongresi, Ankara, 3-7 Mart 2005. s.1-18.

FAO, 2015. The Second Report on the State of the World's Animal Genetic Resources for Food and Agriculture, edited by B.D. Scherf \& D. Pilling. FAO Commission on Genetic Resources for Food and Agriculture Assessments. Rome (available at http://www.fao.org/3/a-i4787e/index.html).

Güler, Z., Keskin, M., Masatçıŏlu, T., Gül, S., Biçer, O., 2007. Effects of breed and lactation period on some characteristics and free fatty acid composition of raw milk from Damascus goats and German Fawn x Hair goat $\mathrm{B}_{1}$ crossbreds. Turkish Journal of Veterinary Animal Science. 31: 347-354.

Güney, O., Cebeci, Z., Torun, O., Biçer, O., 1995. Country Report of Turkey on Small Ruminant Production With Special Reference to The Selection Programme for Increasing Milk Production in Dairy Goat Flock of University of Çukurova. Gabina D. (ed.) In: "Strategies for sheep and goat breeding: CIHEAM-IAMZ, (231p). Meeting of Goint FAO/CIHEAM Metwork on Sheep and Goats, Sidi-Thabet, TUNISIA, 26-28 March 1995. p.185-192.

Keskin, M., Gül, S., 2006. Hatay ili keçi yetiştiriciliğinde Şam keçisi ve Türkiye için önemi. Hasad Hayvancilık. 255: 46-49.

Keskin, M., Avşar, Y.K., Biçer, O., 2004. A comparative study on the milk yield and milk composition of two different goat genotypes under the climate of the eastern Mediterranean. Turkish Journal of Veterinary Animal Science. 31: 347-354.

Kırk, K., Aşkın, Y., Cengiz, F., 2004. Norduz keçilerinin yapay tohumlama ile döl verim karakteristiklerinin belirlenmesi. IV. Ulusal Zootekni Kongresi, Isparta, 1-3 Eylül, 2004. s. 272-279.

Morand-Fehr, P., Richard, A., Tessier, J., Hervieu, J., 2002. Effects of decoquinate on the growth and milk performance of young female goats. Small Ruminant Research. 45: 109-114.

Özder, M., 2006. Keçi ırkları, Keçi Yetiştiriciliği (genişletilmiş ikinci baskı). (Ed. M. Kaymakçı), (s. 34-63). Bornova-İzmir.

Savaş, T., 1995. Yerli ırk hayvanlarımızın korunması konusunda bir tartışma. Animal Enformasyon. 10(11).

Soysal, M.İ., Özkan, E., Gürcan, E.K., 2003. The status of native farm animal genetic diversity in Türkiye and in the World. Trakya Üniversitesi Ziraat Fakültesi Dergisi. 1(3): 1-12.

Sönmez, R., Şengonca, M., Alpbaz, A.G., 1971. Ege Üniversitesi Ziraat Fakültesinde yetiştirilen Malta keçilerinin çeşitli özellikleri ve verimleri üzerinde bir araştırma. Ege Üniversitesi Ziraat Fakültesi Dergisi. 8(1): 57-71.

Sönmez, R., Şengonca, M., Kaymakçı, M., 1973. Ege bölgesinde yetiştirilen çeşitli süt tipi keçilerle bunların melezlerinin adaptasyon durumu ve verim özellikleri üzerinde mukayeseli bir araştırma. IV. Bilim Kongresi, Ankara, 5-8 Kasım 1973. s.1-6.

Sönmez, R. 1974. Melezleme yolu ile yerli keçilerin süt keçisine çevrilme olanakları (34 s.). Ege Üniversitesi Ziraat Fakültesi Yayınları No: 226, E.Ü. Matbaası, Bornova, İzmir. 
Sönmez, R., Kaymakçı, M., 1974. Saanen x Malta oğlaklarının büyütülmesinde süt emme süresinin gelişme gücüne etkisi. Ege Üniversitesi Ziraat Fakültesi Dergisi. 11(1):107120.

Şengonca, M., Kaymakçı, M., Sönmez, R., 1978. Ege bölgesinde yetiştirilen süt keçilerinin melezleme yolu ile islah olanakları (I. Aşama projesi). VI. Bilim Kongresi, VHAG Tebliğleri, TÜBİTAK, 389, seri no: 10, Ankara, s. 579-585.

Şengonca, M., Kaymakçı, M., Koşum, N., Taşkın, T., Steinbach, J., 2002. Batı Anadolu için bir süt keçisi:"Bornova keçisi”. Hayvansal Üretim. 43:79-85.

Şengonca, M., Taşkın, T., Koşum, N., 2003. Saanen x Kıl keçi melezlerinin ve saf Kı1 keçilerinin kimi verim özelliklerinin belirlenmesi üzerine eş zamanlı bir araştırma. Turkish Journal of Veterinary Animal Science. 27:1319-1325.

Şengonca, M., 2001. Türkiye'de Kıl keçisi ıslah çalışmaları. Çanakkale'de Keçi Yetiştiriciliği Paneli, Çanakkale, 12 Haziran, 2001.

Şimşek, Ü.G., Bayraktar, M., 2006. Kıl keçisi ve Saanen x K1l keçisi (F1) Melezlerine ait büyüme ve yaşama gücü özelliklerinin araştırılması. Fırat Üniversitesi Sağlık Bilimleri Dergisi. 20: 229-238.

Şimşek, Ü.G., Bayraktar, M., Gürses, M., 2006. Çiftlik koşullarında Kıl keçilerine ait bazı verim özelliklerinin araştırılması. Fırat Üniversitesi Sağlık Bilimleri Dergisi. 20:221227.

Tölü, C., Savaş, T., 2008. Bazı yerli keçi genotiplerimize yönelik kısa bir değerlendirme. Hasad Hayvanc1l1k. 277: 34-37.

Tölü, C., Yurtman, İ.Y., Savaş, T., 2009. Türk Saanen keçilerinde canlı ağırlık ve değişimi üzerinde değerlendirmeler. Hayvansal Üretim. 50(1): 9-17.

Tölü, C., Savaş, T., 2010. Gökçeada, Malta ve Türk Saanen keçi genotiplerinin döl verim özellikleri bakımından karşılaştırılması. Trakya Üniversitesi Ziraat Fakültesi Dergisi, 7(2): 113-121.

Tölü, C., Savaş, T., 2011. Genotip ve mevsimin keçi sağlığına etkisi: Sağlık uygulaması kayıtları temelinde bir analiz. Çanakkale Tarımı Sempozyumu, Çanakkale, 10-11 Ocak 2011. s. 387-391.

Tölü, C., Topaloğlu, N., Savaş, T., 2011. Gökçeada, Malta ve Türk Saanen çebiçlerinde ağır bir Ektima (Ecthyma contagiosum) olgusu üzerine gözlemler. Hayvansal Üretim. 52(1): 39-43.

Tölü, C. 2009a. Farklı keçi genotiplerinde davranış, sağlık ve performans özellikleri üzerine araştırmalar. Doktora tezi. Çanakkale Onsekiz Mart Üniversitesi, Fen Bilimleri Enstitüsü, Zootekni ABD, 204 s.

Tölü, C. 2009b. Oğlak ishal sıklığının genotip, yıl ve aylara göre değişimi. Hasad Hayvanc1l1k. 295: 50-52.

Vatansever, H., Akçapınar, H., 2006. Lalahan Hayvancılık Merkez Araştırma Enstitüsü’nde yetiştirilen farklı kökenli Ankara keçilerinde büyüme, döl verimi ve tiftik özellikleri. Lalahan Hayvancılık Araştırma Enstitüsü Dergisi. 46(2):1-11.

Yertürk, M., Odabaşığlu, F., 2007. Doğu ve Güneydoğu Anadolu bölgesinde yetiştirilen Renkli Tiftik keçilerinin yarı entansif şartlarda verim özelliklerinin araştırılması. Yüzüncü Yı1 Üniversitesi Veteriner Fakültesi Dergisi.18: 45-50. 